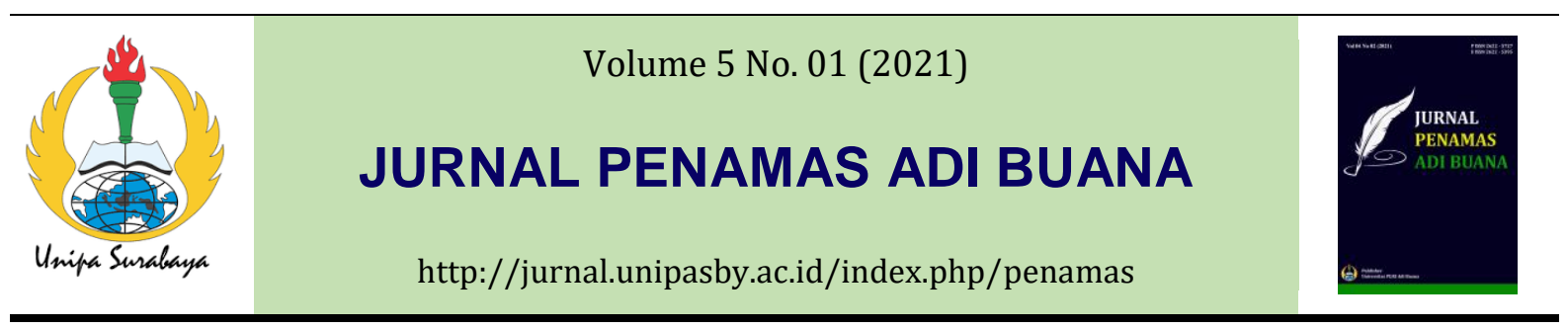

\title{
PENGELOLAAN SAMPAH DI MASA PANDEMI
}

\author{
Sri Widyastuti ${ }^{1 *}$, Joko Sutrisno ${ }^{1}$, Yoso Wiyarno ${ }^{2}$ \\ ${ }^{1}$ Program Studi Teknik Lingkungan, Universitas PGRI Adi Buana Surabaya \\ ${ }^{2}$ Program Studi S2 Pendidikan Jasmani, Universitas PGRI Adi Buana Surabaya \\ *Email: rafirudi@yahoo.co.id
}

\begin{abstract}
Informasi Artikel Abstrak
Kata kunci :

pengelolaan sampah, masa pandemi covid-19, bank sampah

Diterima: 27-04-2021

Disetujui: 11-07-2021

Dipubikasikan: 16-072021

Pandemi covid-19 telah merubah cara pandang dan perilaku manusia dalam banyak hal, terutama yang berkaitan dengan kesehatan dan lingkungan termasuk dalam hal pengelolaan sampah. Pengelolaan sampah di masyarakat yang selama ini dikelola oleh Bank Sampah juga mengalami kemacetan karena umumnya pengelola (petugas) tidak berani kontak langsung dengan sampah. Akibatnya sampah menjadi menumpuk, tidak terkelola dengan baik dan menjadi sumber penyakit. Tujuan pengabdian masyarakat adalah memberikan sosialisasi pengelolaan sampah di masa pandemi. Adapun metode yang digunakan adalah sosialisasi kemudian praktek sesuai Pengelolaan Sampah masa pandemi termasuk praktek pembuatan hand sanitizer. Hasil yang diperoleh adalah semua peserta sebanyak 30 orang sudah dapat menerapkan pengelolaan sampah di masa pandemic dan pemahaman terhadap materi pengabdian sebesar $94 \%$. Selain itu semua peserta juga sudah dapat membuat hand sanititizer secara mandiri.
\end{abstract}

\section{Keywords :}

waste management, the covid-19 pandemic, waste bank

\section{Abstract}

The Covid-19 pandemic has changed people's perspectives and behaviour in many ways, especially those related to health and the environment, especially in waste management. Waste management in the community that has been managed by the Trash Bank has also experienced congestion because generally, the managers (officers) do not dare to come into direct contact with garbage. As a result, waste piles up is not managed correctly and becomes a source of disease. The purpose of community service is to provide socialization of waste management during the pandemic. The method used is socialization and then practices according to Waste Management during the pandemic, including the practice of making hand sanitizers. The results obtained are that all 30 participants have been able to implement waste management during the pandemic and 94\% understanding the service material. In addition, all participants were also able to make hand sanitizer independently. 


\section{PENDAHULUAN}

Pada bulan Maret 2020 Indonesia telah melaporkan adanya 2 kasus COVID-19 dan WHO pada tanggal 11 Maret telah menyatakan COVID-19 sebagai pandemi.

Data penelitian pada10 kondisi yang melibatkan dua virus (SARS-Co-2 dan SARS-CoV-1) dalam lima kondisi lingkungan berbeda (aerosol, plastic baja tahan karat, tembaga, dan kardus). Semua pengukuran eksperimen dilakukan dengan di tiga ulangan. SARS-CoV-2 tetap berada dalam kondisi aerosol selama durasi percobaan (3 jam). Kondisi ini sama dengan yang diamati dengan SARS-CoV-1 (Anand et al., 2020; Kannan et al., 2020; Tarasova et al., 2020). Dari penelitian ini dapat diketahui bahwa virus korona dapat menular melalui media benda padat termasuk sampah dan udara. Pengelolaan sampah di masyarakat melalui sistem Bank Sampah, saat ini mengalami kendala karena masyarakat khawatir sampah yang dikelola menjadi sumber penularan virus corona. Masyarakat tidak lagi mengumpulkan dan menyetorkan sampah keringnya, tetapi lebih memilih membuang sampah di Tempat Sampah Sementara (TPS) karena khawatir tertular virus korona.

Hasil penelitian dari ITS tentang pengelolaan sampah di Surabaya melalui webinar I tentang pengelolaan limbah padat yang diselenggarakan ITB dalam Warmadewanti (2020), menjelaskan tentang kegiatan bank sampah sebelum pandemi dan setelah pandemi yang ditunjukkan dengan gambar sebagai berikut:

WASTE BANK STATUS BEFORE COVID-19 PANDEMIC
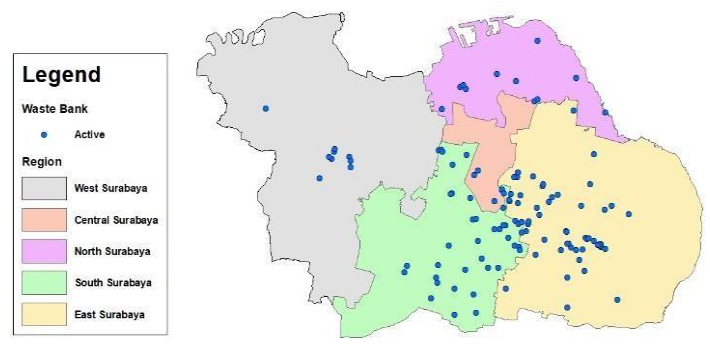

Gambar 1. Bank Sampah sebelum masa pandemi (Warmadewanti, 2020)

WASTE BANK STATUS AFTER COVID-19 PANDEMIC

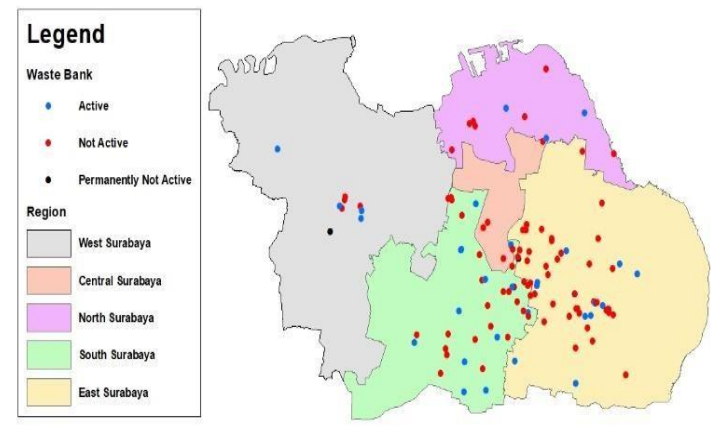

Gambar 2. Bank Sampah pada masa pandemic (Warmadewanti, 2020) 
Gambar 1 menunjukkan adanya kegiatan bank sampah yang tersebar di 5 wilayah Kota Surabaya yang berwarna biru, tetapi setelah adanya pandemi kegiatan bank sampah tersebut berhenti yang ditunjukkan dengan warna merah pada Gambar 2 yang tersebar di 5 wilayah tersebut.

Situasi pandemi ini menyebabkan masyarakat tidak berani melakukan kegiatan mengolah sampah karena takut tertular COVID-19. Untuk mencegah agar tidak tertular virus korona masyarakat diwajibkan untuk melaksanakan protokol kesehatan dengan menerapkan $3 \mathrm{M}$ (memakai masker, mencuci tangan, dan menjaga jarak). Hasil penelitian yang dilaksanakan di Kota Bandung terhadap pelaksanaan protokol kesehatan pada pengelola sampah dijelaskan bahwa (1) seluruhnya (100\%) masyarakat sebagai nasabah Bank Sampah tidak melakukan penyemprotan desinfektan setelah pengumpulan; (2) sebesar 77\% warga masyarakat mengerti dampak yang ditimbulkan jika sampah kering yang dikumpulkan tidak disemprot desinfektan; (3) pengelola Bank Sampah seluruhnya (100\%) tidak melakukan penyemprotan pada tempat penyimpanan; (4) sampah sejenis dikumpulkan jadi satu kemudian tidak disemprot desinfektan; (5) semua masyarakat yang sehat menggunakan masker yang dapat dicuci ulang; (6) hanya 10\% warga yang menggunakan masker sekali pakai setelah digunakan, dirobek, dipotong, atau digunting lalu dikemas rapi sebelum dibuang ke tempat sampah untuk menghindari penyalah gunaan; (7) hanya 20\% petugas kebersihan atau pengangkut sampah dilengkapi dengan APD khususnya sepatu pelindung (safety shoes) yang setiap kali pakai perlu disterilisasi; (9) pemerintah desa belum memberikan petunjuk atau instruksi untuk melakukan protokol kesehatan pada pengelola sampah; (10) belum ada instansi atau universitas lain yang memberikan pemahaman tentang protokol kesehatan pada sampah kering yang akan disetorkan ke Bank Sampah. (Afro, 2021; Herdiani et al., 2021; Meher, 2021; Riyadi \& Larasaty, 2021)

Pada masa pandemi para pengelola Bank Sampah seharusnya memahami dan melaksanakan protokol kesehatan dengan benar serta menggunaan desinfektan untuk mencegah agar tidak tertular oleh virus corona. Masyarakat yang akan menyetorkan sampah maupun pengelola Bank Sampah perlu juga diyakinkan keamanan sampahnya. Baik pengelola sampah maupun nasabah Bank Sampah masih belum bisa membuat desinfektan secara mandiri, sehingga untuk kegiatan sehari-hari masih belum menggunakan desinfektan, sebab jika desinfektan harus beli umumnya mereka berkeberatan.

Berdasarkan permasalahan tersebut maka perlu dilakukan pemberdayaan kepada masyarakat melalui pengabdian kepada masyarakat bidang pengelolaan sampah terutama sampah rumah tangga di masa pandemi.

Adapun luaran yang akan dihasilkan dari pengabdian ini adalah (1) nasabah dan pengelola mengetahui dan melaksanakan protokol kesehatan di masa pandemi, (2) mengetahui alat dan bahan yang dapat digunakan untuk mengilangkan virus corona yaitu desinfektan dan hand sanitizer buatan sendiri dan menerapkan desinfektan pada sampah yang dikelola. 


\section{METODE}

Lokasi kegiatan pengabdian di Kelurahan Gunungsari RT 03 RW IV Kecamatan Dukuh Pakis Kota Surabaya. Waktu pelaksanaan bulan Agustus 2020. Adapun latar belakang peserta adalah nasabah Bank Sampah dan pengelola Bank Sampah. Jumlah peserta yang mengikuti kegiatan pengabdian sebanyak 30 orang.

Metode kegiatan yang dilakukan merupakan kombinasi dari 4 (empat) metode yaitu: (1) Penyadaran atau peningkatan pemahaman terhadap masalah pengelolaan sampah di masa pandemi COVID-19 terutama yang berkaitan dengan protokol kesehatan pada sampah di masa pandemi; (2) Pendidikan yang berkelanjutan tentang pengelolaan sampah di masa pandemi; (3) Pelatihan pembuatan sendiri hand sanitizer; (4) Pendampingan terhadap ipteks yang akan diterapkan.

Sedangkan materi yang disampaikan adalah: (1) Protokol kesehatan dalam pengelolaan sampah di masa pandemi yang mengacu pada Surat Edaran Menteri KLHK Nomor 2/MENLHK/PSLB/PLB.3/3/2020 tentang Pengelolaan Limbah Infeksius (Limbah B3) dan Sampah Rumah Tangga dari Penanganan Corona Virus Disease (COVID-19); (2) Pembuatan desinfektan dan hand sanitizer pada orang dan pada sampah.

Mekanisme pelaksanaan Program PPM di Kelurahan Gunungsari seperti terlihat pada Tabel 1 berikut ini:

Tabel 1. Deskripsi Operasional Kegiatan

\begin{tabular}{lll}
\hline No & Sub Tema & Koordinator Pelaksana \\
\hline 1 & $\begin{array}{l}\text { Pemberian pre test materi tentang Protokol Kesehatan } \\
\text { dalam pengelolaan sampah rumah tangga selama masa } \\
\text { pandemi }\end{array}$ & Dr. Yoso Wiyarno, M.Kes \\
& $\begin{array}{l}\text { Mengubah pola pikir Penerapan Protokol Kesehatan } \\
\text { dalam Pengelolaan Sampah selama masa pandemi }\end{array}$ & Dra. Sri Widyastuti, ST., MSi \\
& $\begin{array}{l}\text { Praktek Penerapan Protokol Kesehatan dalam } \\
\text { Pengelolaan Sampah selama masa pandemi }\end{array}$ & Dra. Sri Widyastuti, ST., MSi \\
4 & $\begin{array}{l}\text { Post Test berkaitan dengan materi yang telah di berikan } \\
5\end{array}$ & Pendampingan Joko Sutrisno, M.Kom \\
6 & Evaluasi & Tim PPM
\end{tabular}




\section{HASIL DAN PEMBAHASAN}

Belum dapat dipastikan berapa lama virus COVID-19 dapat bertahan pada permukaan benda, tetapi besar kemungkinan memiliki karakter yang sama dengan tipe virus corona lainnya. Terbaru terdapat sebuah tinjauan tentang ketahanan virus corona pada permukaan benda yang menunjukkan beragam temuan berkisar antara 2 jam sampai 9 hari. Waktu bertahan sangat tergantung oleh banyak faktor, termasuk bahan permukaan, suhu, kelembaban, dan jenis virus tertentu. Tinjauan yang sama juga menyebutkan bahwa cara efektif membunuh virus dalam satu menit dapat dilakukan dengan desinfektan biasa, seperti alkohol 70\% atau dengan sodium hypochlorite. (Ertiana et al., 2020; Larasati et al., 2020; Nurhafnita et al., 2020; Yuliastri et al., 2020).

Sabun atau deterjen yang biasa digunakan oleh rumah tangga dapat digunakan untuk membersihkan, setelah dibilas cairan desinfektan yang mengandung sodium hypochlorite $0,5 \%$ (setara dengan $5000 \mathrm{ppm}$ atau 1 bagian pembersih mengandung 5\% sodium hypochlorite dicairkan dengan 9 bagian air) dapat digunakan. APD harus selalu digunakan pada saat membersihkan rumah, termasuk masker (Arifin et al., 2021; Mushidah \& Muliawati, 2021; Sekeon et al., 2021; Simbolon et al., 2021)

Adapun gambaran hasil kegiatan pemberdayaan adalah sebagai berikut:

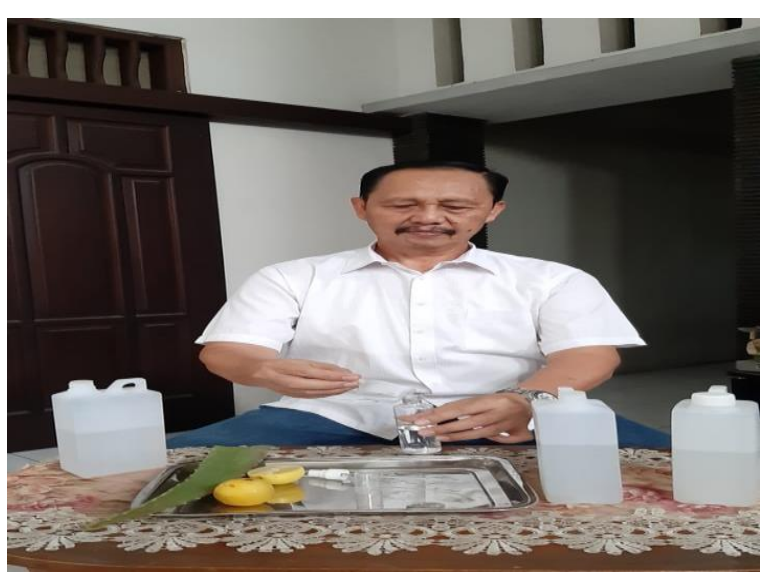

Gambar 3. Sosialisasi SOP Pengelolaan Sampah Masa Pandemi dan Praktek Pembuatan Desinfektan serta Hand Sanitizer

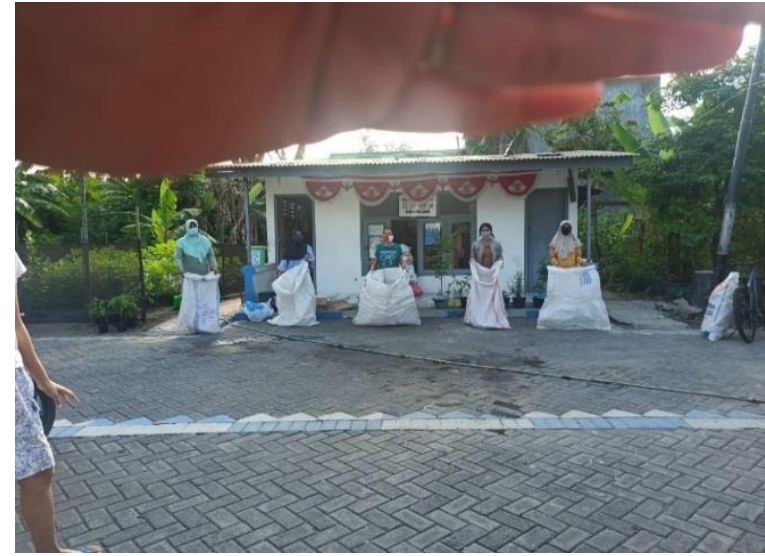

Gambar 4. Praktek Pengelolaan Sampah Masa Pandemi : Petugas Pilah sampah 


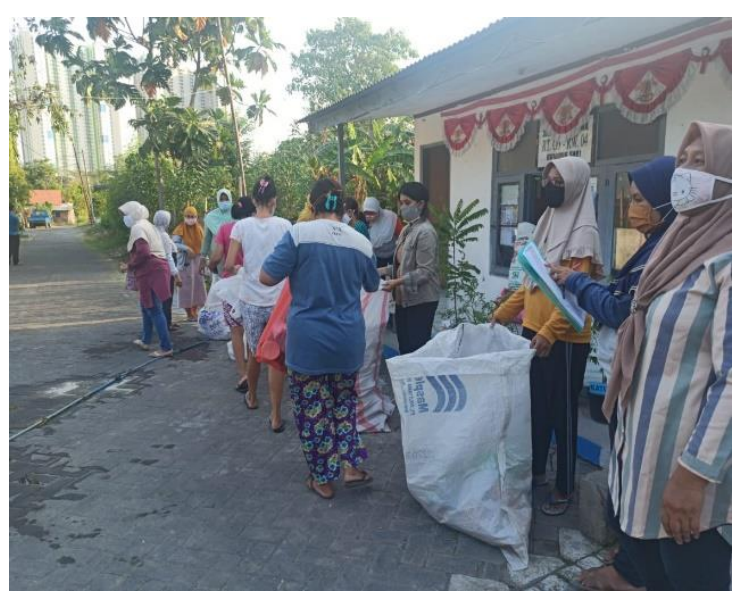

Gambar 5. Praktek Pengelolaan Sampah masa Pandemi : Warga setor sampah kering

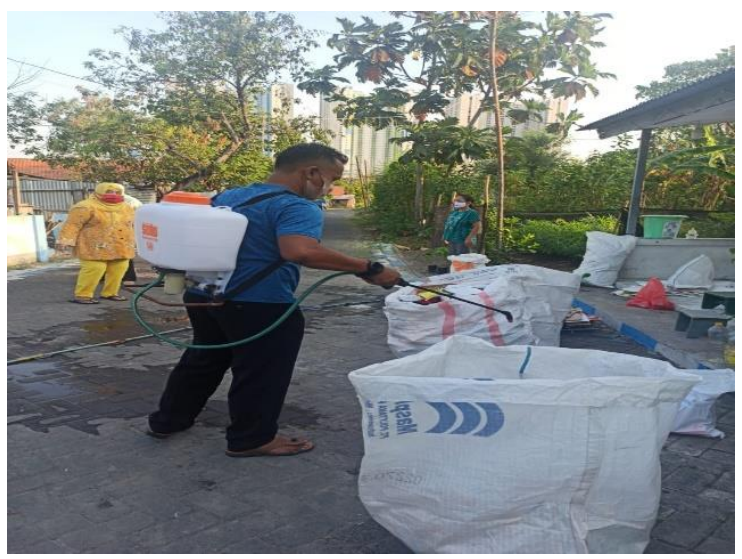

Gambar 7. Sampah kering yang disetorkan warga disemprot desinfektan untuk mencegah penularan virus COVID-19

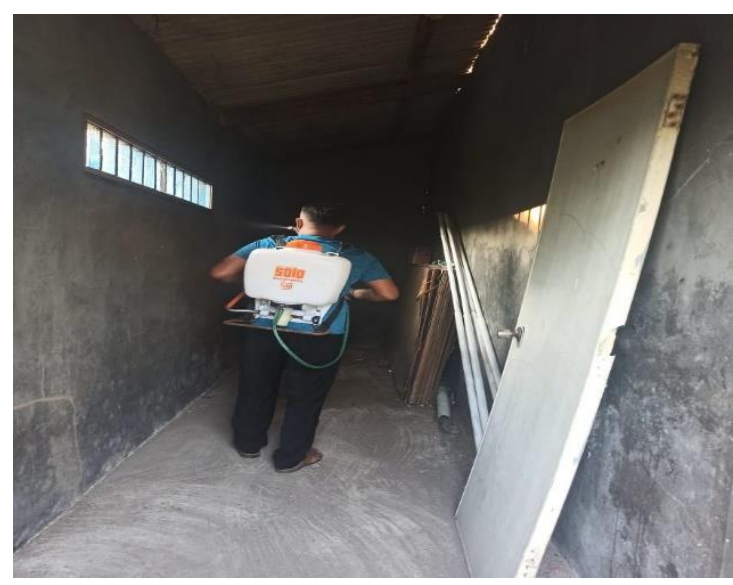

Gambar 6. Gudang penyimpanan sampah kering dis emprot desinfektan sebelum di gunakan untuk menyimpan sampah yang di setorkan warga

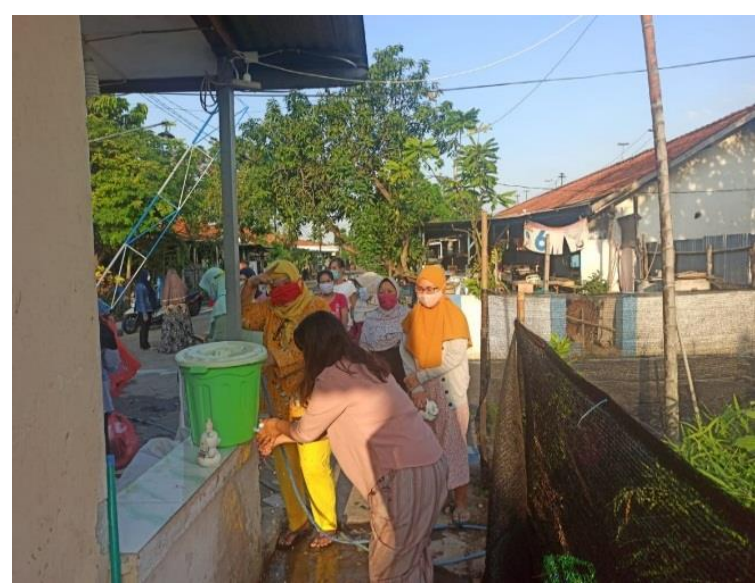

Gambar 8 . Cuci tangan setelah setor sampah

Dari gambar di atas tampak para peserta pemberdayaan masyarakat telah mengikuti semua kegiatan dengan semangat dan antusias. Di sela-sela kegiatan juga banyak peserta yang menanyakan segala sesuatu yang belum diketahui, terutama yang terkait dengan pandemic covid-19. 
Adapun hasil evaluasi postes dengan menggunakan angket hasilnya dapat disajikan dengan tabel 2 sebagai berikut:

Tabel 2. Hasil evaluasi postes

\begin{tabular}{|c|c|c|c|}
\hline \multirow{2}{*}{ No } & \multirow{2}{*}{ Pertanyaan } & \multicolumn{2}{|c|}{ Persentase (\%) } \\
\hline & & $\mathbf{Y a}$ & Tidak \\
\hline & $\begin{array}{l}\text { Apakah warga masyarakat setelah mengumpulkan sampah kering, } \\
\text { melakukan penyemprotan dengan desinfektan? }\end{array}$ & 80 & 20 \\
\hline 2. & $\begin{array}{l}\text { Apakah warga masyarakat mengerti dampak yang ditimbulkan jika } \\
\text { sampah kering yang dikumpulkan tidak disemprot dengan } \\
\text { desinfektan? }\end{array}$ & 100 & 0 \\
\hline 3. & $\begin{array}{l}\text { Apakah ruang penyimpanan sampah (Gudang) yang disetorkan oleh } \\
\text { nasabah sudah disemprot dengan desinfektan? }\end{array}$ & 100 & 0 \\
\hline 4. & $\begin{array}{l}\text { Apakah sampah sejenis dikumpulkan jadi satu kemudian di } \\
\text { semprot dengan desinfektan? }\end{array}$ & 100 & 0 \\
\hline & $\begin{array}{l}\text { Apakah dalam upaya mengurangi timbulan sampah masker, } \\
\text { masyarakat yang sehat diimbau untuk menggunakan masker guna } \\
\text { ulang yang dapat dicuci setiap hari? }\end{array}$ & 100 & 0 \\
\hline 6. & $\begin{array}{l}\text { Apakah sampah masker sekali pakai setelah di gunakan, dirobek, } \\
\text { dipotong, atau digunting lalu dikemas rapi sebelum dibuang ke } \\
\text { tempat sampah untuk menghindari penyalahgunaan? }\end{array}$ & 90 & 10 \\
\hline 7 & $\begin{array}{l}\text { Apakah seluruh petugas kebersihan atau pengangkut sampah wajib } \\
\text { dilengkapi dengan APD khususnya masker dan sarung tangan? }\end{array}$ & 80 & 20 \\
\hline 8. & $\begin{array}{l}\text { Apakah seluruh petugas kebersihan atau pengangkut sampah wajib } \\
\text { dilengkapi dengan APD khususnya sepatu pelindung (safety shoes) } \\
\text { yang setiap kali selesai pakai harus disterilkan? }\end{array}$ & 100 & 0 \\
\hline & $\begin{array}{l}\text { Apakah pemerintah desa sudah memberikan petunjuk atau instruksi } \\
\text { untuk melakukan protokol kesehatan pada sampah kering yang akan } \\
\text { disetorkan ke Bank Sampah? }\end{array}$ & 100 & 0 \\
\hline & $\begin{array}{l}\text { Apakah sudah ada instansi atau universitas lain yang memberikan } \\
\text { pemahaman tentang protokol kesehatan pada sampah kering yang } \\
\text { akan disetorkan ke Bank Sampah? }\end{array}$ & 10 & 90 \\
\hline
\end{tabular}

Secara umum dari hasil angket menyatakan bahwa peserta keberhasilan pelatihan dan pemahaman terhadap materi pelatihan sudah sangat baik, hal ini ditunjukkan bahwa prosentase pada item paling rendah adalah $80 \%$. Untuk prosentase tertinggi $100 \%$ dicapai oleh 6 item dari 10 item secara keseluruhan, sehingga rata-rata prosentase keberhasilan sebesar $94 \%$.

Setelah dilakukan pengabdian masyarakat, maka nasabah Bank Sampah mulai berani memilah sampah dan menyetorkan ke Bank Sampah. Warga masyarakat melakukan protokol kesehatan dengan menggunakan desinfektan dan hand sanitizer buatan sendiri. Masyarakat tidak keberatan untuk melakukan protokol kesehatan karena alat dan bahan yang digunakan untuk melakukan protokol kesehatan mudah dilakukan dan biayanya murah. 
Luaran dari implementasi solusi adalah: (1) peserta pemberdayaan sebagai nasabah Bank Sampah paham mengapa wajib menerapkan protokol kesehatan di masa pandemi; (2) dihasilkan produk desinfektan dan hand sanitizer; (c) menerapkan protokol kesehatan pada sampah yang dipilah dan disetorkan ke Bank Sampah.

Adapun yang menjadi faktor pendorong pelaksanaan program adalah: (1) peserta pengabdian adalah warga masyarakat yang sadar akan pentingnya pengelolaan sampah, sehingga mereka berusaha untuk tetap mengelola sampah meskipun di masa pandemi; (2) sebagian peserta terbiasa mengikuti pelatihan sejenis sehingga meskipun pemberian materi secara daring mereka tetap bisa memahami. Sedangkan faktor penghambatnya adalah: (1) banyaknya informasi negatif tentang COVID-19 membuat ketakutan yang berlebihan; (2) sebagian peserta awam dengan pembelajaran daring.

Berdasarkan bukti ilmiah, COVID-19 dapat menular dari manusia ke manusia melalui kontak erat dan droplet, tidak melalui udara. Orang yang paling berisiko tertular COVID-19 adalah orang yang kontak erat dengan pasien COVID-19 termasuk yang perawatnya. Rekomendasi standar untuk mencegah penyebaran infeksi adalah melalui cuci tangan secara teratur, menerapkan etika batuk dan bersin, menghindari kontak secara langsung dengan ternak dan hewan liar serta menghindari kontak dengan siapapun yang menunjukkan gejala penyakit pernapasan seperti batuk dan bersin. (Arifin et al., 2021; Karuniawati \& Putrianti, 2020; Sekeon et al., 2021; Simbolon et al., 2021; Suharmanto, 2020).

\section{KESIMPULAN}

Selama masa pandemi COVID-19 pengelola sampah dapat melakukan aktivitasnya dengan menerapkan protokol kesehatan. Pelaksanaan protokol kesehatan dapat dilakukan mengunakan alat dan bahan yang murah dan mudah diperoleh. Warga masyarakat Gunungsari terutama nasabah Bank Sampah dapat kembali memilah sampah dan menyetorkan sampah kering ke Bank Sampah. Faktor pendukung yang dapat memicu keberhasilan kegiatan pemberdayaan adalah karena peserta adalah kader lingkungan yang memiliki kesadaran pentingnya pengelolaan sampah mandiri. Meskipun kegiatan tidak semuanya dilaksanakan secara luring, namun pemahaman tentang materi penerapan protokol kesehatan pada pengelolaan sampah dapat dipahami oleh peserta pemberdayaan rata-rata sebesar $94 \%$.

\section{DAFTAR PUSTAKA}

Afro, R. C. (2021). ANALISIS FAKTOR YANG MEMPENGARUHI KEPATUHAN TERHADAP PROTOKOL KESEHATAN SAAT PANDEMI COVID-19 PADA MASYARAKAT JAWA TIMUR: PENDEKATAN HEALTH BELIEF MODEL. Journal of Community Mental Health and Public Policy, 3(1). https://doi.org/10.51602/cmhp.v3i1.43 
Anand, S. P., Chen, Y., Prévost, J., Gasser, R., Beaudoin-Bussières, G., Abrams, C. F., Pazgier, M., \& Finzi, A. (2020). Interaction of human ACE2 to membrane-bound SARS-CoV-1 and SARSCoV-2 S glycoproteins. Viruses, 12(10). https://doi.org/10.3390/v12101104

Arifin, Z., Albayani, M. I., Fatmawati, B. R., \& ... (2021). Gerakan Masyarakat Sadar Masker Di Era New Normal Melalui Sosialisasi Protokol Pencegahan Covid-19 Di Desa Mambalan. ... Kepada Masyarakat, 2(1).

Ertiana, D., Ulfa, M., Aspiyani, A., Silaturrokhmah, S., \& Prastiwi, N. W. Y. (2020). Peningkatan Peran Serta Masyarakat Dalam Pencegahan Covid-19 di Desa Maduretno Kecamatan Papar Kabupaten Kediri. Darmabakti: Jurnal Pengabdian Dan Pemberdayaan Masyarakat, 1(2). https://doi.org/10.31102/darmabakti.2020.1.2.23-33

Herdiani, I., Sahroni, O., Sasyari, U., Suhartini, T., Siti Nuramanah, R., Maulida, S., Supriatiningsih, R., Isna Annur, A., \& Dinar, M. (2021). Edukasi Protokol Kesehatan Di Masa Adaptasi Kebiasaan Baru. Prosiding Seminar Nasional Lppm Ump, O(0).

Kannan, S., Subbaram, K., Ali, S., \& Kannan, H. (2020). Molecular characterization and amino acid homology of nucleocapsid (N) Protein in SARS-CoV-1, SARS-CoV-2, MERS-CoV, and bat coronavirus. In Journal of Pure and Applied Microbiology (Vol. 14, Issue 1). https://doi.org/10.22207/JPAM.14.SPL1.13

Karuniawati, B., \& Putrianti, B. (2020). GAMBARAN PERILAKU HIDUP BERSIH DAN SEHAT (PHBS) DALAM PENCEGAHAN PENULARAN COVID-19. Jurnal Kesehatan Karya Husada, 8(2). https://doi.org/10.36577/jkkh.v8i2.411

Larasati, A. L., Gozali, D., \& Haribowo, C. (2020). Penggunaan Desinfektan dan Antiseptik Pada Pencegahan Penularan Covid-19 di Masyarakat. Majalah Farmasetika, 5(3). https://doi.org/10.24198/mfarmasetika.v5i3.27066

Meher, C. (2021). GAMBARAN PERILAKU MASYARAKAT KOTA MEDAN TERKAIT PELAKSANAAN PROTOKOL KESEHATAN COVID 19. Jurnal Kedokteran STM (Sains Dan Teknologi Medik), 4(1).

Mushidah, \& Muliawati, R. (2021). Pengetahuan dan Sikap dengan Kepatuhan Penggunaan Masker Sebagai Upaya Pencegahan Penyebaran Covid-19 Pada Pedagang UMKM. Jurnal Ilmiah Permas: Jurnal Ilmiah STIKES Kendal, 11(1).

Nurhafnita, N., Bulotio, N. F., \& Umela, S. (2020). DESIMINASI PEMBUATAN DESINFEKTAN SENDIRI BAHAN PENYEMPROTAN CEGAH COVID-19 DI KELURAHAN TANJUNG KRAMAT KOTA GORONTALO. Jurnal Abdimas Gorontalo (JAG), 3(2). https://doi.org/10.30869/jag.v3i2.642

Riyadi, R., \& Larasaty, P. (2021). FAKTOR YANG BERPENGARUH TERHADAP KEPATUHAN MASYARAKAT PADA PROTOKOL KESEHATAN DALAM MENCEGAH PENYEBARAN $\begin{array}{llll}\text { COVID-19. Seminar Nasional Official } & \text { Statistics, }\end{array}$ https://doi.org/10.34123/semnasoffstat.v2020i1.431

Sekeon, F. M., Rumayar, A. A., \& Tucunan, A. A. T. (2021). Gambaran Perilaku Masyarakat Terhadap Pencegahan Corona Virus Diseases (Covid 19) Di Lingkungan Iii Kelurahan Tingkulu Kota .... Kesmas, 10(1).

Simbolon, V. A., Manullang, P. O., \& Sitanggang, Y. E. (2021). Memutus Mata Rantai Penularan Virus Covid-19 melalui Penggunaan Masker dan Penggunaan Alat Dispenser Hand Sanitizer di Tempat Ibadah. Poltekita: Jurnal Pengabdian Masyarakat, 2(1). 
https://doi.org/10.33860/pjpm.v2i1.290

Suharmanto. (2020). Perilaku Masyarakat dalam Pencegahan Penularan Covid-19 Community Behavior in Prevention of Covid-19 Transmission. Kedokteran Universitas Lampung, 4.

Tarasova, O., Ivanov, S., Filimonov, D. A., \& Poroikov, V. (2020). Data and text mining help identify key proteins involved in the molecular mechanisms shared by SARS-CoV-2 and HIV-1. Molecules, 25(12). https://doi.org/10.3390/molecules25122944

Yuliastri, W. O., Zulbayu, L. O. M. A., Isrul, M., Hasanuddin, S., \& Lolok, N. (2020). Edukasi Penggunaan Hand Sanitizer Dan Cairan Desinfektan Untuk Pencegahan Penyebaran Covid-19 Di Wilayah Desa Talia Kecamatan Abeli Kota Kendari. Jurnal Mandala Pengabdian Masyarakat, 1(2). https://doi.org/10.35311/jmpm.v1i2.15

Warmadewanti, (2020), Potensi Penelitian Limbah Padat, Webinar 1 Aliansi Limbah Padat ITB

Wildayanti, (2020), Pengelolaan Sampah Masa pandemi Covid 19, Astra Eco-Talk 2020 Webinar Strategi Mengelola Sampah di Tengah Pandemi COVID-19 17 April 2020 